\title{
Chromosomal evolutionary dynamics of four multigene families in Coreidae and Pentatomidae (Heteroptera) true bugs
}

\author{
Vanessa Bellini Bardella ${ }^{1}$ José Antônio Marin Fernandes ${ }^{2} \cdot$ \\ Diogo Cavalcanti Cabral-de-Mello ${ }^{1}$
}

Received: 11 January 2016 / Accepted: 22 June 2016 / Published online: 5 July 2016

(C) Springer-Verlag Berlin Heidelberg 2016

\begin{abstract}
Previous chromosome mapping of multigene families in Pentatomomorpha (Heteroptera) insects, which was restricted to the major rDNA, revealed remarkable conservation of number of clusters and chromosomal positions. Aiming to understand the chromosomal organization and evolutionary patterns of multigene families in karyotypes of Heteroptera, we performed a chromosomal mapping using four distinct multigene families in representatives of Coreidae (ten species) and Pentatomidae (five species). A single pair of the major rDNA cluster (18S rDNA probe) and a single pair of the minor rDNA cluster (5S rDNA probe), both terminally located were primarily observed, being, in most species, located in distinct chromosomes. However, some alternative patterns were also observed. In species in which the U2 snDNA and $\mathrm{H} 4$ gene clusters were mapped, they were mainly located in one autosomal pair each, wherein the $\mathrm{H} 4$ gene cluster was located in different positions. Our data suggest that the karyotype diversity reported in Coreidae is not reflected in the distribution diversity of multigene families. This contrasts with the data for Pentatomidae, with a conserved gross karyotype but a discrete diversity in the location of the clusters of multigene families, indicating genome dynamics for these markers. The findings are discussed to shed light on the possible causes for the
\end{abstract}

Communicated by Q. Xia.

Diogo Cavalcanti Cabral-de-Mello

mellodc@rc.unesp.br

1 Departamento de Biologia, Instituto de Biociências/ IB, UNESP-Universidade Estadual Paulista, Rio Claro 13506-900, Brazil

2 Instituto de Ciências Biológicas, Universidade Federal do Pará (UFPA), Belém, Brazil conservation or variation observed and to assist in understanding the chromosomal evolutionary trends in the group.

Keywords Fluorescence in situ hybridization $\cdot \mathrm{H} 4$ histone $\cdot$ rDNA $\cdot$ U2 snDNA

\section{Introduction}

Repetitive DNAs comprise a large part of the eukaryotic genomes, represented by dispersed repeats as the transposable elements (TE) or sequences in tandem arrangement (Charlesworth et al. 1994; López-Flores and GarridoRamos 2012). Among these, some multigene families are tandemly organized, and the chromosomal location of these sequences has been useful for the elucidation of chromosomal evolution in different groups, including insects (see for example Cabrero et al. 2009; Nguyen et al. 2010; Cabral-de-Mello et al. 2011a, b; Bardella et al. 2013; Anjos et al. 2015). The multigene families most used as chromosomal markers in insects; i.e., rDNAs, histone genes and, to a lesser extent, U snDNA, have revealed variable patterns for the number and location of the clusters, depending on the group studied.

In the suborder Heteroptera, which comprises approximately 40,000 species with holocentric chromosomes (Ueshima 1979; Weirauch and Schuh 2011), the mapping of multigene families is restricted to $18 \mathrm{~S}$ rDNA (Panzera et al. 2012; Bardella et al. 2013; Chirino et al. 2013; Golub et al. 2015). Among the infraorders studied, the data have revealed diversity in the number and location of clusters in Triatoma, and conservation in the genus Rhodnius (Reduviidae, Cimicomorpha) (Panzera et al. 2012; Pita et al. 2013). In Pentatomomorpha representatives, the occurrence of two 
Table 1 Geographic distribution, chromosomal complement and location of multigene families in different species of the suborder Heteroptera

\begin{tabular}{|c|c|c|c|c|c|c|c|c|c|c|c|}
\hline \multirow{2}{*}{$\begin{array}{l}\text { Family } \\
\text { Species }\end{array}$} & \multirow[t]{2}{*}{ Locality } & \multirow[t]{2}{*}{$2 n$} & \multicolumn{2}{|c|}{ RDNA $18 \mathrm{~S}$} & \multicolumn{2}{|c|}{ RDNA 5S } & \multirow[t]{2}{*}{ LISC } & \multicolumn{2}{|c|}{$\begin{array}{l}\text { Histone } \\
\mathrm{H} 4\end{array}$} & \multicolumn{2}{|c|}{$\begin{array}{l}\text { SnDNA } \\
\text { U2 }\end{array}$} \\
\hline & & & $\mathrm{NC}$ & $\mathrm{L}$ & $\mathrm{NC}$ & $\mathrm{L}$ & & $\mathrm{NC}$ & $\mathrm{L}$ & $\mathrm{NC}$ & $\mathrm{L}$ \\
\hline \multicolumn{12}{|l|}{ Coreidae } \\
\hline Acanonicus hahni (Stål, 1860) & Londrina-PR & $18+\mathrm{X} 0$ & 2 & At & 2 & At & No & 2 & $\mathrm{Ai}$ & 2 & At \\
\hline Anisoscelis foliaceus (Fabricius, 1803) & Rio Claro-SP & $24+2 \mathrm{~m}+\mathrm{X} 0$ & 2 & At & 4 & At & No & 2 & At & 2 & At \\
\hline Chariesterus armatus (Thunberg, 1825) & Rio Claro-SP & $22+2 \mathrm{~m}+\mathrm{X} 0$ & 2 & At & $\mathrm{S}$ & $\mathrm{S}$ & Yes & 2 & $\mathrm{Ai}$ & - & - \\
\hline Holhymenia histrio (Herbst, 1784) & Rio Claro-SP & $24+2 \mathrm{~m}+\mathrm{X} 0$ & 2 & At & 2 & At & No & 2 & At & 2 & At \\
\hline Hypselonotus fulvus (De Geer, 1773) & Rio Claro-SP & $16+2 m+X 0$ & 2 & At & 2 & At & Yes & - & - & 4 & At \\
\hline Leptoglossus gonagra (Fabricius, 1775) & Rio Claro-SP & $18+2 \mathrm{~m}+\mathrm{X} 0$ & 2 & $\mathrm{~m}$ & 2 & $\mathrm{Ai}$ & No & 2 & $\mathrm{Ai}$ & 2 & At \\
\hline Leptoglossus neovexillatus Allen, 1969 & Rio Claro-SP & $18+2 \mathrm{~m}+\mathrm{X} 0$ & 2 & At & 2 & At & No & 2 & $\mathrm{Ai}$ & 4 & At \\
\hline Machtima crucigera (Fabricius, 1803) & Rio Claro-SP & $18+2 \mathrm{~m}+\mathrm{X} 0$ & 2 & At & 2 & At & No & - & - & - & - \\
\hline Phtia picta (Drury, 1770) & Londrina-PR & $18+2 \mathrm{~m}+\mathrm{X} 0$ & 2 & At & 2 & At & No & 2 & At & 2 & At \\
\hline Zicca nigropunctata (De Geer, 1773) & Rio Claro-SP & $20+2 \mathrm{~m}+\mathrm{X} 0$ & 2 & At & 2 & At & Yes & 2 & At & 2 & At \\
\hline \multicolumn{12}{|l|}{ Pentatomidae } \\
\hline Arvelius albopunctatus (De Geer, 1773) & Rio Claro-SP & $12+X Y$ & 2 & At & 4 & At, Ast & Yes & - & - & - & - \\
\hline Mormidea notulifera Stål 1860 & Rio Claro-SP & $12+X Y$ & 2 & At & 4 & At, Ast & Yes & 2 & $\mathrm{Ai}$ & 2 & $\mathrm{Ai}$ \\
\hline Mormidea v-luteum (Lichtenstein, 1796) & Rio Claro-SP & $12+\mathrm{XY}$ & 2 & At & 4 & At, Ast & Yes & 2 & $\mathrm{Ai}$ & - & - \\
\hline Oebalus poecilus (Dallas, 1851) & Rio Claro-SP & $12+X Y$ & 4 & At, Xt, Yt & 2 & At & No & 2 & At & 2 & At \\
\hline $\begin{array}{l}\text { Proxys albopunctulatus (Palisot de Beauvois, } \\
\text { 1811) }\end{array}$ & Rio Claro-SP & $12+\mathrm{XY}$ & 2 & At & 2 & At & No & - & - & - & - \\
\hline
\end{tabular}

LISC located in the same chromosome, $N C$ number of clusters, $L$ location, - no results for the species, $A$ autosome, $t$ terminal, st subterminal, $i$ interstitial, $S$ spread clusters

terminal sites per diploid genome is remarkable (Bardella et al. 2013).

The Pentatomomorpha infraorder includes families exhibiting distinct macro-chromosomal features, i.e., diploid numbers. This differentiation is observed, for example, between Coreidae and Pentatomidae. The former displays a wide variability ranging from $2 n=13$ to $2 n=21$, while $2 n=12+\mathrm{XY}$ is conserved in the Pentatomidae (Ueshima 1979). This chromosomal characteristic of pentatomids led to speculations about the absence of chromosomal rearrangements (Rebagliati et al. 2005). To understand the chromosomal organization and evolutionary patterns for multigene family in karyotypes of Heteroptera, we examined, here, the chromosomal distribution of rDNAs using fluorescence in situ hybridization (FISH) with 18S rDNA and 5S rDNA probes in fifteen species belonging to the Pentatomidae and Coreidae families revealing the relationship between these two markers. Moreover, we mapped the location of $\mathrm{H} 4$ histone gene clusters in eleven species and U2 snDNA in ten representatives of both families. This is the first study mapping 5S rDNA, U2 snDNA and the H4 histone gene in heteropterans. The data are discussed in an evolutionary context, in an attempt to reveal the causes of chromosomal divergence and chromosomal organization for the sequences studied.

\section{Materials and methods}

\section{Animals and chromosome preparations}

A total of 59 adult males from 15 species were analyzed (Table 1). The testes were removed from anesthetized insects and fixed in modified Carnoy's solution (absolute ethanol: acetic acid, 3:1) with subsequent storage in a freezer at $-20{ }^{\circ} \mathrm{C}$. The pronotum and legs of insects were stored in $100 \%$ ethanol in a freezer at $-20{ }^{\circ} \mathrm{C}$ for the extraction of genomic DNA according to Sambrook and Russell (2001). Slides were prepared using a portion of the testis, which was macerated in $50 \%$ acetic acid and, then, dried on a hot plate at $45-50{ }^{\circ} \mathrm{C}$.

\section{Multigene families amplification}

The partial sequence of 5S rDNA was obtained by polymerase chain reaction (PCR) using genomic DNA from Anisoscelis foliaceus (Coreidae). The partial sequences of U2 snDNA and histone H4 were obtained by PCR from genomic DNA of A. foliaceus (Coreidae) and Mormidea notulifera (Pentatomidae). The PCR was performed using the primer pair for $5 \mathrm{~S}$ rDNA described by Cabral-de-Mello et al. (2010), U2 snDNA from Bueno et al. (2013) and H4 
Fig. 1 Fluorescence in situ hybridization using $18 \mathrm{~S}$ (green) and $5 \mathrm{~S}$ rDNA $($ red $)$ probes in six species of Coreidae (a-d) and Pentatomidae (e-f). Metaphase I of a Holhymenia histrio, b Anisoscelis foliaceus, c Hypselonotus fulvus, d Chariesterus armatus, e Mormidea notulifera and $\mathbf{f}$ Oebalus poecilus. Arrowheads indicate the sex chromosomes and $\mathbf{m}$ shows the m-chromosomes. The inset in $\mathbf{d}$ shows the two signals for rDNAs separated Scale bar $5 \mu \mathrm{m}$ (color figure online)
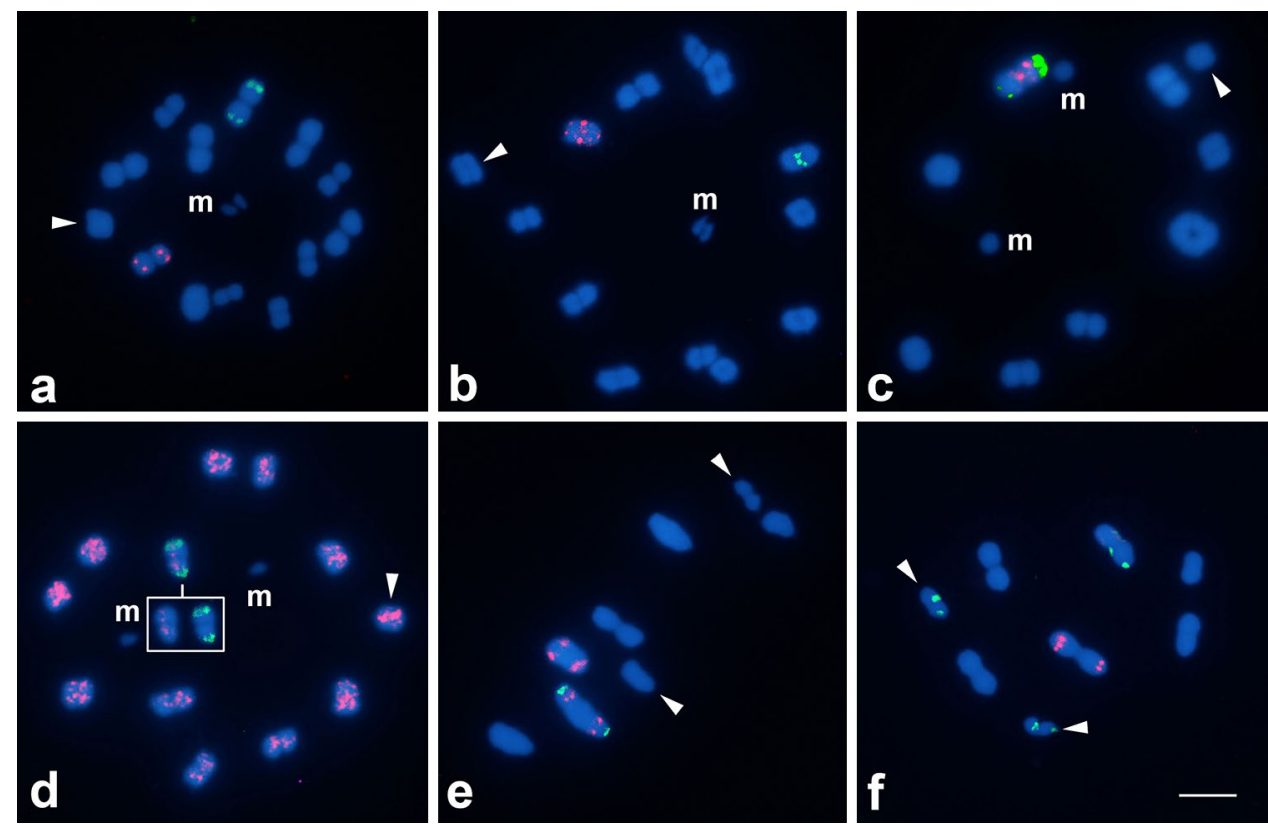

histone from Pineau et al. (2005). The amplified fragments were sequenced and compared with sequences deposited in GenBank, confirming the isolation of intended sequences. The partial sequence of $18 \mathrm{~S}$ rDNA was obtained from a previously isolated clone from the genome of Dichotomius semisquamosus (GenBank Accession Number GQ443313, Cabral-de-Mello et al. 2010).

\section{Fluorescence in situ hybridization}

The plasmid containing the 18S rDNA was labeled by nick translation using biotin-14-dATP (Invitrogen, San Diego, CA, USA). During PCR, the amplified products of $5 \mathrm{~S}$ rDNA, U2 snDNA and histone H4 DNAs were labeled with digoxigenin-11-dUTP (Roche, Mannheim, Germany).

Single- or two-color FISH was performed according to Pinkel et al. (1986), with modifications from Cabral-deMello et al. (2010). The 5S rDNA probe obtained from A. foliaceus was used in all insects, and the other probes (U2 snDNA and histone H4) obtained from A. foliaceus and $M$. notulifera were applied to insects from the Coreidae and the Pentatomidae families, respectively. Probes labeled with digoxigenin-11-dUTP were detected using anti-digoxigenin-rhodamine (Roche), and the probe labeled with biotin-14-dATP was detected using a streptavidin Alexa Fluor 488 conjugate (Invitrogen). The preparations were counterstained using 4',6-diamino-2'-phenylindole dihydrochloride (DAPI) and mounted using VECTASHIELD (Vector, Burlingame, CA, USA). The preparations were observed using an Olympus microscope BX61 equipped with a fluorescence lamp and appropriate filters. The photographs were recorded using a DP70 cooled digital camera.
The images were merged and optimized for brightness and contrast using Adobe Photoshop CS2 software.

\section{Results}

For the ten Coreidae representatives studied, the diploid number ranged from $2 n=19$ to $2 n=27$, with invariably $\mathrm{X} 0$ sex chromosome system. The presence of m-chromosomes was noticed in nine of them, except in Acanonicus hahni. The five species of Pentatomidae exhibited $2 n=12+\mathrm{XY}$.

For all studied species, the 18S rDNA sites were located primarily in autosomes, being observed two clusters (one bivalent), invariably with terminal location (Fig. 1; Table 1). Variant patterns related to specific chromosome were observed only in two species, Leptoglossus gonagra (Table 1) with the clusters in the m-chromosomes, and Oebalus poecilus in which in addition to the autosomal clusters, we observed hybridization signals in both sex chromosomes (Fig. 1f; Table 1). The number of clusters for 5S rDNA varied from two to four per diploid genome (Table 1), being the only exception Chariesterus armatus. This species showed spread signals in all chromosomes, except the m-chromosomes (Fig. 1d; Table 1). In addition to the variation in number of clusters, distinct locations were also observed for this gene family, with terminal, subterminal or interstitial location (Table 1; Fig. 1). The chromosomal relationship for the two classes of rDNA was addressed through two-color FISH, revealing only in six species, the two rDNA sequences located in the same chromosome (C. armatus, Hypselonotus fulvus, Zicca 
Fig. 2 Examples of fluorescence in situ hybridization using histone $\mathrm{H} 4$ (red, $\mathbf{a}-\mathbf{f})$ and $\mathrm{U} 2$ snDNA (red, $\mathbf{g}-\mathbf{l}$ ) as probes in species of Coreidae $(\mathbf{a}-\mathbf{c}, \mathbf{g}-\mathbf{j})$ and Pentatomidae (d-f, $\mathbf{k}-\mathbf{l})$. Metaphase I of a Holhymenia histrio, b Leptoglossus gonagra, c and $\mathbf{g}$ Anisoscelis foliaceus, $\mathbf{d}$ and $\mathbf{I}$ Mormidea notulifera, $\mathbf{e}$ Mormidea v-luteum, $\mathbf{f}$ and $\mathbf{k}$ Oebalus poecilus, $\mathbf{h}$ Leptoglossus neovexillatus, i Phtia picta and $\mathbf{j}$ Zicca nigropunctata. Arrowheads indicate the sex chromosomes and $\mathbf{m}$ shows the m-chromosomes. Scale bar $5 \mu \mathrm{m}$ (color figure online)
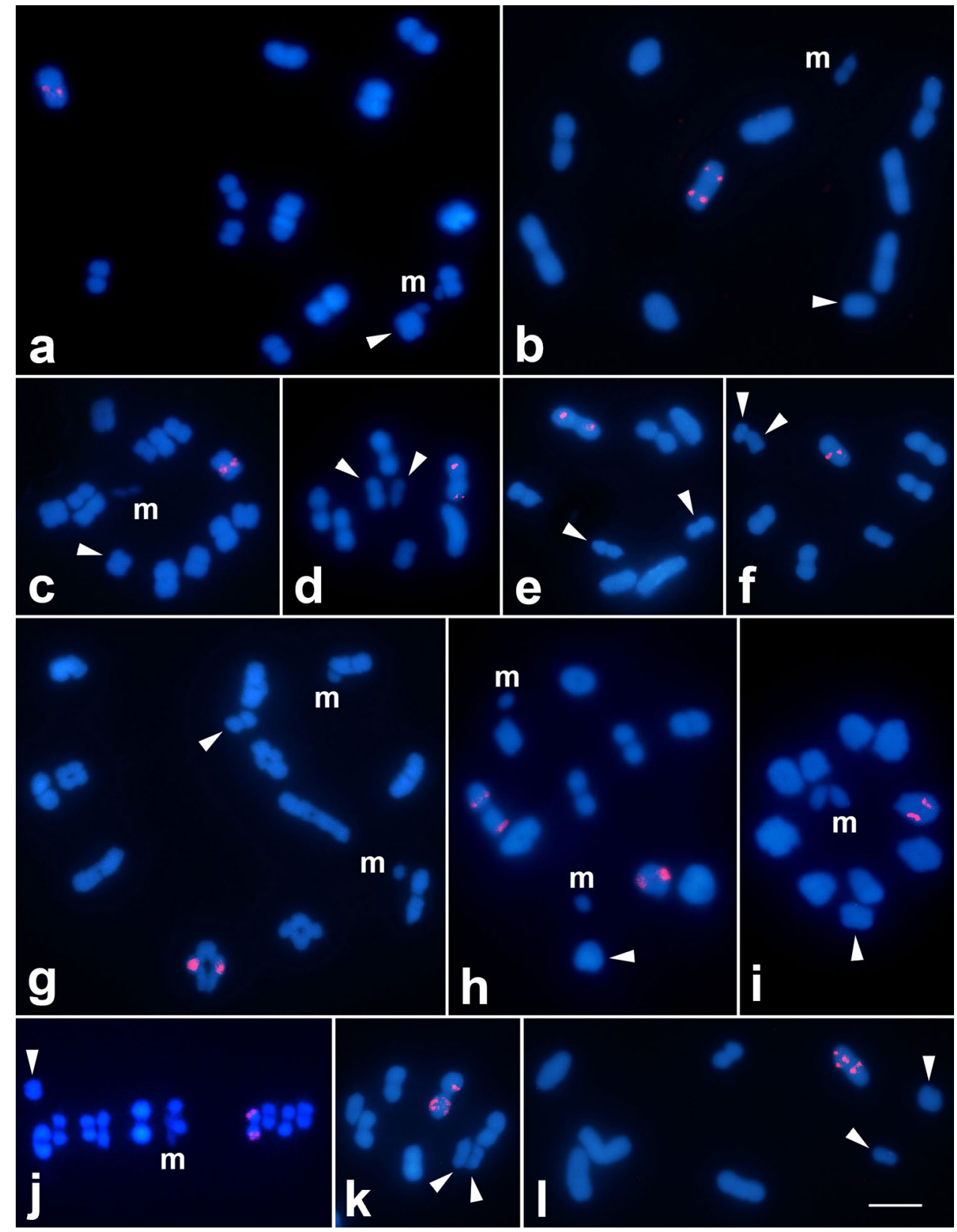

nigropunctata, Arvelius albopunctatus, M. notulifera and Mormidea v-luteum) (Fig. 1c-e; Table 1).

For the $\mathrm{H} 4$ histone gene clusters, FISH results were obtained for eleven species. A remarkable conservation of the number of clusters was observed, with one autosomal bivalent harboring the signals. However, the specific location for the clusters was variable, with interstitial or terminal placement (Fig. 2a-f; Table 1). In the ten species analyzed for the distribution of U2 snDNA clusters, we observed a prevalent number of two sites (one bivalent) restricted to autosomes, except in L. zonatus and H. fulvus, which exhibited four clusters distributed in two distinct autosomal pairs (Table 1). The localization of U2 snDNA cluster was predominantly in the chromosome termini (Fig. 2g-1; Table 1), except in M. notulifera (Fig. 2l).

\section{Discussion}

Of the 15 species studied here, the karyotypes are described for the first time for five of them; i.e., Leptoglossus neovexillatus, A. foliaceus, Z. nigropunctata, Machtima crucigera and $M$. notulifera. The chromosomal characteristics for the other species were identical to the previous descriptions (Bowen 1922; De Castro 1947; Ueshima 1979; Colombo and Bidau 1985; Papeschi and Mola 1989; Rebagliati et al. 
2001; Souza et al. 2008). For Coreidae, the diploid number variability observed here, was also previously noticed (Bressa et al. 2005; Franco et al. 2006), like the presence of $\mathrm{X} 0$ sex system in males and the occurrence of m-chromosomes (see details in Papeschi and Bressa 2006), except in A. hahni. The conservative karyotype observed for the five Pentatomidae species, i.e., $2 n=12+\mathrm{XY}$, is a recurrent character for the group (Rebagliati et al. 2005).

Among the 15 species studied, eight were previously analyzed for 18S rDNA mapping (A. hahni, A. albopunctatus, C. armatus, Holhymenia histrio, H. fulvus, L. gonagra, M. v-luteum and Phtia picta) (Table 1), and an identical pattern was noticed, with the occurrence of two rDNA sites (one bivalent). Of these, C. armatus, L. gonagra, H. fulvus, H. histrio, A. albopunctatus and M. v-luteum were sampled in a distinct geographic area compared to that sampled in this work, and no interpopulational variability was noticed, suggesting stability of the rDNA sites at the intraspecific level. The published data for 18S rDNA mapping in Pentatomidae reveal that the modal pattern is two autosomal clusters per diploid genome, described in eight species. Variant cases have been documented; for example, one to three clusters per diploid genome with variable locations involving autosomes and one or both sex chromosomes (González-García et al. 1996; Papeschi et al. 2003; Grozeva et al. 2011; Bardella et al. 2013). These variable situations could be considered as derived characteristics. Among previously studied Coreidae as well as the species analyzed in this study, no change in the number of $18 \mathrm{~S}$ rDNA sites per diploid genome was evident. Moreover, the location was conserved terminally in one autosomal pair, except in L. gonagra, with clusters in the m-chromosomes (Bardella et al. 2013). These data suggest that the mechanisms that could cause dispersion of $18 \mathrm{~S}$ rDNA sites are operating more efficiently in Pentatomidae than in Coreidae. Generally, among different groups of insects, similar variability to Pentatomidae was observed, caused by distinct mechanisms such as ectopic recombination and movement associated with transposable elements. These events were suggested, for example, in Scarabaeidae beetles (Coleoptera) (Cabral-de-Mello et al. 2011a), Reduviidae (Heteroptera) (Panzera et al. 2012), Acrididae grasshoppers (Orthoptera) (Cabrero and Camacho 2008), butterflies from the Papilionoidea superfamily (Lepidoptera) (Nguyen et al. 2010) and species of the genus Chironomus (Diptera) (Gunderina et al. 2015). In contrast, groups with low variability for $18 \mathrm{~S}$ rDNA as seen in Coreidae were also described, even within the suborder Heteroptera, such as the genus Rhodnius (Pita et al. 2013).

In this study, 5S rDNA was mapped in Heteroptera species for the first time, and the results revealed more variability in comparison with $18 \mathrm{~S}$ rDNA. As for $18 \mathrm{~S}$ rDNA, the 5S rDNA was the most variable in Pentatomidae than in
Coreidae. Rebagliati et al. (2005) proposed that the maintenance of chromosome number in Pentatomidae would reflect stability in the genome. However, the results of rDNAs mapping suggest that although the chromosome number is constant, different mechanisms are operating, causing amplification and spread of these repetitive DNAs without the occurrence of macro-chromosomal changes. Genome dynamics for repetitive DNAs in pentatomids was previously proposed by analysis of different amplification patterns of $\mathrm{A}+\mathrm{T}$ or $\mathrm{G}+\mathrm{C} \mathrm{C}$-bands in the genus Edessa (Bardella et al. 2014). A similar situation occurs within the Heteroptera suborder in the Reduviidae subfamily, in which the karyotype $2 n=20+\mathrm{XY}$ is maintained in most representatives of Triatoma and in four species of Tingidae lace bugs with $2 n=12+\mathrm{XY}$, but with variation in the number and position of $18 \mathrm{~S}$ rDNA clusters (Panzera et al. 2012; Golub et al. 2015). For Acrididae grasshoppers in related species with the same chromosome number, a high dynamics for the number and location of $5 \mathrm{~S}$ rDNA clusters was noticed, with these patterns attributed to amplification, association with transposable elements and movement through extrachromosomal circular DNA (eccDNA) (Cabral-de-Mello et al. 2011b), which are mechanisms that may operate in the Heteroptera genomes. The extreme case for action of these possible mechanisms is $C$. armatus with spread clusters, as previously described in the grasshopper Rhammatocerus brasiliensis (Oliveira et al. 2011), and in Gymnotus paraguensis fish (Da Silva et al. 2011).

The variability observed concerning the relationship between the chromosomal location of 18S and 5S rDNA, being both markers located in distinct or in the same chromosome, could be attributed to the mechanisms that cause movement of rDNAs. The low rate of co-location between rDNA18S and 5S clusters is common among insects, observed in Orthoptera (Cabral-de-Mello et al. 2011b) and Coleoptera (Cabral-de-Mello et al. 2011a). In these organisms, the authors reported that the independent locations of multigene families of $5 \mathrm{~S}$ and $18 \mathrm{~S}$ would be indications of separate evolutionary patterns, a characteristic which is also present in Heteroptera. The few cases of co-location apparently occurred randomly, as proposed for different families of protists by Drouin and Tsang (2012).

Concerning H4 histone clusters' position, the variability noticed suggests at least the occurrence of inversions, causing intra-chromosomal position changes for the $\mathrm{H} 4$ histone cluster in representatives of both families. In addition, there is also a possibility of transposition events. The suggestion of chromosomal homology in the bivalent harboring of the $\mathrm{H} 4$ histone between the species is not feasible due to the slight variation in size of the chromosomes. The occurrence of one autosomal bivalent harboring the $\mathrm{H} 4$ histone could represent the ancestral placement for this gene for Coreidae and Pentatomidae. Similar conservation patterns were 
reported for other insects, such as Acrididae grasshoppers, in which $\mathrm{H} 4$ and $\mathrm{H} 3$ histone sites occurred frequently interstitially in one autosomal bivalent (Cabrero et al. 2009), like for $\mathrm{H} 3$ histone in some species of tortricid moths (Šíchová et al. 2013). According to Cabrero et al. (2009), this high conservation suggests strong purifying selection acting at the chromosomal level for $\mathrm{H} 3$ and $\mathrm{H} 4$ histone gene location. A similar degree of conservation with two autosomal clusters (one bivalent) was also noticed in some Scarabaeinae beetles (Cabral-de-Mello et al. 2011a) and in three species of aphids (Mandrioli and Manicardi 2013). Two clusters were also reported in the female of the aphid Diuraphis noxia (Aphididae), but they were located in the X chromosome (Novotná et al. 2011). Considering the phylogenetic relationship of Heteroptera and Aphididae (Song et al. 2012), it could be suggested that the number of clusters is conserved among these organisms, but the location is variable at the intra- and inter-chromosomal level in distinct species.

Regarding the U2 snDNA sites, the occurrence of hybridization signals terminally located in a bivalent appears to be a conserved characteristic for the Coreidae and Pentatomidae families, despite few variations noticed. Stability for number of sites was also observed in the fish genus Astyanax (Characiformes, Characidae) (Silva et al. 2015), in contrast with the variability in the number of sites observed in some species of fish of the family Batrachoididae (Úbeda-Manzanaro et al. 2010) and grasshoppers belonging to the subfamily Melanoplinae (Palacios-Gimenez et al. 2013). Another feature of the U2 snRNA sites in heteropterans was the location restricted to autosomes, a feature that is also recurrent in different species of fish (Úbeda-Manzanaro et al. 2010; Utsunomia et al. 2014), except for Gymnotus pantanal, with U2 snDNA clusters in the sex chromosomes (Utsunomia et al. 2014).

The predominance of the four multigene families in the terminal region of chromosomes was also previously documented for $18 \mathrm{~S}$ and 5S rDNA in plants with holocentric chromosomes (Roa and Guerra 2012, 2015). It is apparently a trend in some species with holocentric chromosomes, suggesting that this placement was favored during evolution or that the non-terminal sites are tighter constraints to be established (Roa and Guerra 2012), but the random occurrence of these markers in chromosomal termini could not be ruled out. The same hypothesis could be applied for U2 snDNA and histone genes, at least for the species studied here. Finally, the diploid number variability reported for Coreidae is not directly reflected in the distribution diversity of chromosomal markers used in this work, revealing stability for multigene families. This contrasts with the data for Pentatomidae, in which the gross karyotype is conserved, but a discrete diversity in location of the clusters of multigene families was noticed, indicating genome dynamics for these markers.

Acknowledgments This study was supported by Fundação de Amparo à Pesquisa do Estado de São Paulo (FAPESP) (Process Number 2014/11763-8), Coordenadoria de Aperfeiçoamento de Pessoal de Nível Superior (CAPES), and Conselho Nacional de Desenvolvimento Científico e Tecnológico $(\mathrm{CNPq})$. We are also grateful to the anonymous reviewers for valuable comments. DCCM and JAMF were the recipients of a research productivity fellowship from the Conselho Nacional de Desenvolvimento Científico e TecnológicoCNPq (Process Numbers 304758/2014-0, 311403/2012-3, respectively) and VBB was a recipient of PNPD scholarship.

\section{Compliance with ethical standards}

Funding This study was founded by Fundação de Amparo a Pesquisa do Estado de São Paulo-FAPESP (Process Number 2014/11763-8) and Coordenadoria de Aperfeiçoamento de Pessoal de Nível SuperiorCAPES.

Conflict of interest Vanessa Bellini Bardella declares that she has no conflict of interest. José Antônio Marin Fernandes declares that he has no conflict of interest. Diogo Cavalcanti Cabral-de-Mello declares that he has no conflict of interest.

Ethical approval All applicable international, national, and/or institutional guidelines for the care and use of animals were followed.

\section{References}

Anjos A, Ruiz-Ruano FJ, Camacho JPM, Loreto V, Cabrero J, Souza MJ, Cabral-de-Mello DC (2015) U1 snDNA clusters in grasshoppers: chromosomal dynamics and genomic organization. Heredity 114:207-219

Bardella VB, Fernandes T, Vanzela ALL (2013) The conservation of number and location of $18 \mathrm{~S}$ sites indicates the relative stability of rDNA in species of Pentatomomorpha (Heteroptera). Genome 56:425-429

Bardella VB, Grazia J, Fernandes JAM, Vanzela ALL (2014) High diversity in $\mathrm{CMA}_{3} / \mathrm{DAPI}$-banding patterns in heteropterans. Cytogenet Genome Res 142(1):46-53

Bowen RH (1922) Notes on the occurrence of abnormal mitosis in spermatogenesis. Biol Bull 43:184-203

Bressa MJ, Larramendy M, Papeschi AG (2005) Heterochromatin characterization in five species of Heteroptera. Genetica 124:307-317

Bueno D, Palacio-Gimenez OM, Cabral-de-Mello DC (2013) Chromosomal mapping of repetitive DNAs in Abracris flavolineata reveal possible ancestry for the B chromosome and surprisingly H3 histone spreading. PLoS One 8:e66532

Cabral-de-Mello DC, Moura RC, Martins C (2010) Chromosomal mapping of repetitive DNAs in the beetle Dichotomius geminatus provides the first evidence for an association of 5S rRNA and histone $\mathrm{H} 3$ genes in insects, and repetitive DNA similarity between the B chromosome and A complement. Heredity 104:393-400

Cabral-de-Mello DC, Moura RC, Martins C (2011a) Cytogenetic mapping of rRNAs and histone $\mathrm{H} 3$ genes in 14 species of Dichotomius (Coleoptera, Scarabaeidae, Scarabaeinae) beetles. Cytogenet Genome Res 134:127-135

Cabral-de-Mello DC, Cabrero J, López-León MD, Camacho JPM (2011b) Evolutionary dynamics of 5S rDNA location in acridid grasshoppers and its relationship with $\mathrm{H} 3$ histone gene and $45 \mathrm{~S}$ rDNA location. Genetica 139:921-931 
Cabrero J, Camacho JP (2008) Location and expression of ribosomal RNA genes in grasshoppers abundance of silent and cryptic loci. Chromosome Res 16:595-607

Cabrero J, López-León MD, Teruel M, Camacho JPM (2009) Chromosome mapping of $\mathrm{H} 3$ and $\mathrm{H} 4$ histone gene clusters in 35 species of acridid grasshoppers. Chromosome Res 17:397-404

Charlesworth B, Sniegowski P, Stephan W (1994) The evolutionary dynamics of repetitive DNA in eukaryotes. Nature 371:215-220

Chirino MG, Papeschi AG, Bressa MJ (2013) The significance of cytogenetics for the study of karyotypes evolution and taxonomy of water bugs (Heteroptera, Belostomatidae) native to Argentina. Comp Cytogenet 7:111-129

Colombo PC, Bidau CJ (1985) Estudios cromosómicos en heterópteros argentinos. I. Los cromosomas meióticos de cinco espécies de Coreidae. Physis 43:29-40

Da Silva M, Matoso DA, Vicari MR, De Almeida MC, Margarido VP, Artoni RF (2011) Physical mapping of 5S rDNA in two species of knifefishes: Gymnotus pantanal and Gymnotus paraguensis (Gymnotiformes). Cytogenet Genome Res 134(4):303-307

De Castro YGP (1947) Comportamento dos cromossômios no gênero Hypselonotus (Hemiptera-Coreidae). An Esc Super Agric Luiz de Queiroz 4:313-325

Drouin G, Tsang C (2012) 5S rRNA gene arrangements in protists: a case of nonadaptive evolution. J Mol Evol 74(5-6):342-351

Franco MJ, Bressa MJ, Papeschi AG (2006) Karyotype and male meiosis in Spartocera batatas and meiotic behavior of multiple sex chromosome in Coreidae (Heteroptera). Eur J Entomol 103(1):9-16

Golub NV, Golub VB, Kuznetsova VG (2015) Variability of $18 \mathrm{~S}$ rDNA loci in four lace bug species (Hemiptera, Tingidae) with the same chromosome number. Comp Cytogenet 9(4):513-522

González-García JM, Antonio C, Suja JA, Rufas JS (1996) Meiosis in holocentric chromosomes: chromatid ends of sex univalents in Graphosoma italicum (Heteroptera). Chromosome Res 4(2):124-132

Grozeva S, Kuznetsova VG, Anokhin BA (2011) Karyotypes, male meiosis and comparative FISH mapping of $18 \mathrm{~S}$ ribosomal DNA and telomeric (TTAGG) $)_{\mathrm{n}}$ repeat in eight species of true bugs (Hemiptera, Heteroptera). Comp Cytogenet 5(4):355-374

Gunderina L, Golygina V, Broshkov A (2015) Chromosomal organization of the ribosomal RNA genes in the genus Chironomus (Diptera, Chironomidae). Comp Cytogenet 9(2):201-220

López-Flores I, Garrido-Ramos MM (2012) The repetitive DNA content of eukaryotic genomes. Cytogenet Genome Res 7:1-28

Mandrioli M, Manicardi GC (2013) Chromosomal reveals a dynamic organization of the histone genes in aphids (Hemiptera: Aphididae). Entomologia 1(1):e2

Nguyen P, Sahara K, Yoshido A, Marec F (2010) Evolutionary dynamics of rDNA clusters on chromosomes of moths and butterflies (Lepidoptera). Genetica 138(3):343-354

Novotná J, Havelka J, Starý P, Koutecký P, Vítková M (2011) Karyotype analysis of the Russian wheat aphid, Diuraphis noxia (Kurdjumov) (Hemiptera: Aphididae) reveals a large X chromosome with rRNA and histone gene families. Genetica 139(3):281-289

Oliveira NL, Cabral-de-Mello DC, Rocha MF, Loreto V, Martins C, Moura RC (2011) Chromosomal mapping of rDNAs and H3 histone sequences in the grasshopper Rhammatocerus brasiliensis (Acrididae, Gomphocerinae): extensive chromosomal dispersion and co-localization of $5 \mathrm{~S} \mathrm{rDNA} / \mathrm{H} 3$ histone clusters in the $\mathrm{A}$ complement and B chromosome. Mol Cytogenet 4:24

Palacios-Gimenez OM, Castillo ER, Martí DA, Cabral-de-Mello DC (2013) Tracking the evolution of sex chromosome systems in Melanoplinae grasshoppers through chromosomal mapping of repetitive DNA sequences. BMC Evol Biol 13:167

Panzera Y, Pita S, Ferreiro MJ, Ferrandis I, Lages C, Pérez R et al (2012) High dynamics of rDNA cluster location in kissing bug holocentric chromosomes (Triatominae, Heteroptera). Cytogenet Genome Res 138(1):56-67

Papeschi AG, Bressa MJ (2006) Evolutionary cytogenetics in Heteroptera. J Biol Res 5:3-21

Papeschi AG, Mola LM (1989) Meiotic studies in Acanonicus hahni (Stål) (Coreidae, Heteroptera). I. Behaviour of univalent in desynaptic individuals. Genetica 80(1):31-38

Papeschi AG, Mola LM, Bressa MJ, Greizerstein EJ, Lía V, Poggio L (2003) Behaviour of ring bivalents in holokinetic systems: alternative sites of spindle attachment in Pachylis argentines and Nezara viridula (Heteroptera). Chromosome Res 11:725-733

Pineau P, Henry M, Suspène R, Marchio A, Dettai A, Debruyne R et al (2005) A universal primer set for PCR amplification of nuclear histone $\mathrm{H} 4$ genes from all animal species. Mol Biol Evol 22(3):582-588

Pinkel D, Straume T, Gray JW (1986) Cytogenetic analysis using quantitative, high-sensitivity, fluorescence hybridization. Proc Natl Acad Sci 83(9):2934-2938

Pita S, Panzera F, Ferrandis I, Galvão C, Gómez-Palacio A, Panzera Y (2013) Chromosomal divergence and evolutionary inferences in Rhodniini based on the chromosomal location of ribosomal genes. Mem Inst Oswaldo Cruz 108(3):376-382

Rebagliati PJ, Mola LM, Papeschi AG (2001) Karyotype and meiotic behavior of the holokinetic chromosomes of six Argentine species of Pentatomidae (Heteroptera). Caryologia 54:339-347

Rebagliati PJ, Mola LM, Papeschi AG, Grazia J (2005) Cytogenetic studies in Pentatomidae (Heteroptera): a review. J Zool Sys Evol Res 43:199-213

Roa F, Guerra M (2012) Distribution of 45S rDNA sites in chromosomes of plants: structural and evolutionary implications. BMC Evol Biol 12:225

Roa F, Guerra M (2015) Non-random distribution of 5S rDNA sites and its association with 45S rDNA in plant chromosomes. Cytogenet Genome Research 146(3):243-249

Sambrook J, Russell DW (2001) Molecular cloning. A laboratory manual. Cold Spring Harbor Laboratory Press, New York

Šíchová J, Nguyen P, Dalíková M, Marec F (2013) Chromosomal evolution in tortricid moths: conserved karyotypes with diverged features. PLoS One 8(5):e64520

Silva DMZA, Utsunomia R, Pansonato-Alves JC, Oliveira C, Foresti $\mathrm{F}$ (2015) Chromosomal mapping of repetitive DNA sequences in five species of Astyanax (Characiformes, Characidae) reveals independent location of $\mathrm{U} 1$ and $\mathrm{U} 2$ snRNA sites and association of $\mathrm{U} 1$ snRNA and 5S rDNA. Cytogenet Genome Res 146(2):144-152

Song N, Liang AP, Bu CP (2012) A molecular phylogeny of Hemiptera inferred from mitochondrial genome sequences. PLoS One 7(11):e48778

Souza HV, Castanhole MMU, Bicudo HEMC, Costa LAA, Itoyama MM (2008) Morphological patterns of the heteropycnotic chromatin and nucleolar material in meiosis and spermiogenesis of some Pentatomidae (Heteroptera). Genet Mol Biol 31(3):686-691

Úbeda-Manzanaro M, Merlo MA, Palazón JL, Cross I, Sarasquete S, Rebordinos L (2010) Chromosomal mapping of the major and minor ribosomal genes (GATA) ${ }_{n}$ and U2 snRNA gene by doublecolour FISH in species of the Batrachoididae family. Genetica 138(7):787-794

Ueshima N (1979) Hemiptera II: Heteroptera. In: John B (ed) Animal cytogenetics. Gebrüder Bornträger, Berlin Stuttgart

Utsunomia R, Scacchetti PC, Pansonato-Alves JC, Oliveira C, Foresti F (2014) Comparative chromosome mapping of U2 snRNA and 5S rRNA genes in Gymnotus species (Gymnotiformes, Gymnotidae): evolutionary dynamics and sex chromosome linkage in $G$. pantanal. Cytogenet Genome Res 142(4):286-292

Weirauch C, Schuh R (2011) Systematics and evolution of Heteroptera: 25 years of progress. Annu Rev Entomol 56:487-510 